\title{
An evaluation of community-led archaeology projects funded through the Heritage \\ Lottery Fund: Two Case Studies
}

\section{William Mitchell and Kevin Colls}

\section{Notes on Contributors}

William is the Project Archaeologist for the Centre of Archaeology at Staffordshire University. William has supervised and published numerous archaeological projects throughout the United Kingdom and has extensive experience in leading, delivering and consulting on archaeological and heritage projects. He is a qualified teacher and regularly works with school groups and on community-led projects.

Kevin Colls is the lead Archaeological Project Manager for the Centre of Archaeology at Staffordshire University. He has directed and published archaeological projects throughout the United Kingdom and has over 15 years' experience in professional development-led archaeology.

\begin{abstract}
Community archaeology projects have gained popularity for many reasons. In the UK, professional archaeology has championed involving community volunteers in Heritage Lottery Fund (HLF) supported archaeological projects. We review two HLF-supported community-led projects, including the positive and measurable outcomes in conjunction with the challenges that each presented. We discuss the advantages and disadvantages of working with community volunteers. Due to our direct responsibility for supervising the volunteers and all the archaeological aspects of these projects, we are able to analyse their success and delivery, and the benefits and drawbacks of using the HLF for project funding. This includes how they regulate access to funding, and how they evaluate the process. Finally, we examine commercial archaeological companies and the extent to which the HLF holds them accountable for outcomes, questioning how these outcomes feed into archaeological research frameworks and contribute to professional practice.
\end{abstract}


Keywords: Community Archaeology, Heritage Lottery Fund (HLF), Public Archaeology, New Place, Volunteer Archaeology 


\section{Introduction}

In the past 20 years, the UK has seen community archaeology projects increase. Several factors have contributed to the success of community archaeology as a specific approach within the wider discipline. There are a wealth of opportunities for groups and individuals to become involved in 'live' archaeological projects, and a better understanding of the potential benefits to communities. But why have these projects become so commonplace?

Partly, the increase in community archaeology projects can be seen as an acknowledgment of the many benefits that such projects offer. For archaeologists, especially those engaged in commercial, developer-led archaeology, community projects offer the chance for involvement in unique, varied, and engaging work. These types of project can bring together individuals and groups from all walks of life and from all age groups, working towards a common goal. Both archaeologists in commercial archaeology and in universities often face the same challenge of disseminating their work more widely than a client-based report or academic publication. Community archaeology offers one potential solution. This has led to the creation of outreach and public engagement posts at archaeological organizations across the UK. For archaeologists within the university sector, community engagement represents an effective way to quantify their work's impact and reach, particularly those working within the Research Excellence Framework (REF 2021). For individuals and community groups, archaeology offers the chance to work with experts and professionals on projects that are regionally or nationally important, or to work on sites that are deeply embedded in the local community. There is also a social aspect, as those involved often meet for the first time and develop working and personal relationships with each other through shared working practices. For others, these projects can offer the chance to upskill and gain valuable experience as they work towards further studies or a career in archaeology (Simpson 2008, 12). 
The increased occurrence of community archaeological projects can also partly be seen as a result of changes and diversification within the archaeological profession. With commercial archaeology receiving much of its funding through development projects (Department for Communities and Local Government 2012; Ministry of Housing Communities and Local Government 2019), any slow-down in commercial opportunity significantly impacts archaeological companies. Community archaeology projects have, as a result, increasingly become a means to access different funding streams in the face of reduced developer-led opportunities. There is though, a 'risk with such projects that they are designed and delivered following little or no consultation with the communities for whom they are intended' (Thomas $2014,26)$. In her summary of the XArch project, Simpson also asks the question of the validity of these types of project: 'does archaeology affect community values or is community archaeology simply a means for archaeologists successfully to secure funding for their fieldwork?' (Simpson 2009, 53). Likewise, these types of projects can be problematic from the perspective of engagement and dissemination.

The main financial contributor to this type of project in the UK has been the Heritage Lottery Fund (HLF) (Maeer 2017, 40). The HLF is a non-departmental public body accountable to Parliament via the Department for Digital, Culture, Media and Sport (DCMS). It awards grants raised from the proceeds National Lottery ticket sales to successful applicants from notfor-profit organisations, local authorities and private individuals.

Here we discuss the variation and scope of community archaeology projects and consider HLF funding of such projects through two recent examples undertaken in the West Midlands under our direction. These projects originated from a commercial tendering process, funded through the HLF. We discuss the validity of the work by assessing the setup and motivations behind each project, the volunteer experience, the outputs, and the challenges faced before, during and after the projects. Ultimately, we conclude that each project should be 
viewed as successful, and offer important guidelines for best-practice in the field of community archaeology.

\section{Community Archaeology or Volunteer Archaeology?}

A community archaeology project should have the interests of the community at its heart. We could define 'community' by geographical location - including all the individuals, groups and communities living within - or as representing individuals or groups sharing common interests, beliefs or experiences with no emphasis on where they live. The question of validity in community archaeology has been raised previously, as Simpson and Williams have discussed:

If the archaeological community is to keep justifying the millions of pounds that are being invested in these projects by the likes of the Heritage Lottery Fund and (directly and indirectly) by the UK government, the character of the way these projects are deemed 'successful' must be appraised from both theoretical and practical perspectives. (Simpson and Williams 2008, 73).

The variation and scope of community archaeology as a discipline makes specific classification problematic. The Council for British Archaeology indicates that a key principle is that involvement of non-professional archaeologists and volunteers is encouraged' (Thomas $2010,5)$. Taking this further, its 'distinguishing characteristic is the relinquishing of at least partial control of a project to the local community' (Marshall 2002, 211). The most authentic type of community archaeology project would be one that members of a local community group has organized, designed, developed and undertaken with technical support from archaeological professionals. This 'bottom up' approach would also have strong links to the communities' own local and collective history (Thomas 2014, 25, Grant, 2014, 149, Carman 2005, Reid 2008).

Another type are projects, which have volunteers from the local community in mind but that professional archaeologists initiate. These 'top down' projects rely on a volunteer 
workforce to succeed. Thomas makes the point that, 'community archaeology projects carried out as "top-down" ventures must demonstrate due consideration for their intended communities, however these "communities" are defined or identified' (our italics) (Thomas, 2014, 26). Funding for 'top down' projects can come from varied sources, including the HLF if a suitable partner can be found fitting their eligibility criteria.

Other variations exist between these two main types of community archaeological project. For some projects, community volunteers exhibit more independence and responsibility, and for other projects the professional archaeologists have complete autonomy. The resulting outputs of these project types retain similarities, of which the personal and combined satisfaction of all stakeholders and contributors involved in the project is paramount. In reality, this may not always happen. Tensions between professionals, academics and the rest of society have always been present but as Schadla-Hall states,

'...in the changing society in which we live, access, involvement and openness are increasingly demanded and the increasing trend towards freedom of information will influence our often-inaccessible data, as indeed it should' (Schadla-Hall 1999, 148).

A successful community archaeology project may result in training the next generation of archaeologists and spark enough interest in an individual to follow a career in archaeology. The experiences of Steve Winterton (2014), an army veteran turned archaeologist, during the Operation Nightingale project on Salisbury plain are a good example of this.

The benefits of community archaeology to those involved are great - there is opportunity for exchange of ideas, expertise and knowledge. People can find shared values and contribute to a common narrative. The importance that public perception has in the future of archaeology is often underplayed. These community projects play a role in ensuring that archaeology and heritage remain integral parts of British societal and cultural psyche. As Belford states: 
...neither academic nor commercial archaeology are themselves sustainable without community archaeology, for community archaeology nurtures public support for heritage in its widest sense and it is only with public support that any form of archaeology will continue' (Belford 2014, 40).

\section{The Heritage Lottery Fund}

Successful recipients of a HLF award have met their rigorous funding goals and are likely to have seen extensive competition for this funding. According to their own published data, the HLF are the largest dedicated funder of heritage in the UK and they have awarded $£ 7.7$ billion to over 42,000 projects since 1994 (HLF 2018a). These projects are extremely varied and do not necessarily always include community involvement or archaeology, but they should make a lasting difference to the local community. Without the opportunity that this funding affords, many projects would not happen. The influence and importance of the HLF in the heritage sector remains huge, resulting in an institution that holds a prodigious responsibility for selecting and supporting certain projects.

In order to be selected by the HLF programme, projects should usually originate from not-for-profit organizations, private individuals and partnerships led by not-for-profit organizations (HLF, 2018b). Commercial archaeological companies indirectly access this funding by supplying services to a grant recipient through the competitive tendering process.

But how is access to this funding regulated and to what extent is the process evaluated? Are these commercial archaeological companies, effectively sub-contractors, held accountable for project outcomes? The HLF naturally expects a return on public money, and it places expectations for project outcomes. How do these outcomes feed into archaeological research frameworks and contribute to developing professional practice?

When funding for a community project comes directly from an agency such as this, it has a direct influence on what type of project it becomes. The HLF is clear in its outcomes for 
the projects it awards; 'we fund projects that make a lasting difference for heritage, people and communities in the UK' (HLF 2017b).

Approved HLF-funded projects require self-evaluation throughout to gauge their success against their stated objectives (HLF 2017a, 17). Successful projects (those considered to make a 'lasting difference for heritage, people and communities') must have produced all of the outputs stated in their submission documents. By ensuring that projects adhere to these criteria, the HLF ensures that their projects have similar monitored outcomes. Although the HLF assesses the overall outcomes of each grant, the individual applicants are responsible for assessing their own project.

\section{Case Studies}

What follows is an overview of two community-based archaeology projects, which we directly supervised through firstly Birmingham Archaeology (a former commercial archaeological contractor) followed by the Centre of Archaeology, Staffordshire University. Each project received significant HLF funding, initiated by the sites' respective owners and, from the outset, the project designs contained archaeological elements. Both projects can be considered as challenging locations for community archaeology: one at a globally important site and the other in a churchyard involving human remains. Community groups themselves did not prepare or design these projects and the archaeological tasks represented only a small percentage of the overall project budget. However, without the community archaeological element, the case for funding from the HLF may have been less convincing as archaeology offered a practical and efficient way to engage volunteers in relatively high numbers, therefore helping to ensure a greater community impact. Without the HLF, it is unlikely that these projects would have happened. Both projects contain best practices, whilst both also encountered challenges and problems. The lessons learned have resonance for future community projects. 


\section{Dig for Shakespeare-New Place, Stratford-upon-Avon}

\section{Background to the project}

Playwright and poet William Shakespeare's final, no longer surviving, home in Stratford-uponAvon was known as New Place. Shakespeare purchased the late-medieval house, constructed in c. 1483 , in 1597 . After demolition in the $18^{\text {th }}$ century, the site of New Place remained an open plot of land, eventually passing into the guardianship of the Shakespeare Birthplace Trust (SBT), a charity maintaining and preserving the surviving Shakespearean properties, collections and archives. In 2010, the SBT decided that the long-neglected story of New Place could be enhanced and communicated through modern archaeological methods leading to a reinvention of the site, exhibits and visitor attractions.

The project revolved around archaeological excavation. The objectives were to reinform and shed light on this enigmatic house, uncover archaeological evidence for the life and times of William Shakespeare and New Place, and to engage the local community, and national and international visitors with the archaeological project. The SBT initially funded the project via several income streams, most notably the HLF, but also Stratford-upon-Avon District Council, Historic England and private companies. The SBT conceived the project as an excavation with associated activities (post-excavation duties). It became clear once commissioned, that further funding would be necessary to support additional archaeological tasks.

The HLF accepted a funding bid from the SBT on several assurances. Among others, an archaeological report was to be completed and distributed, public talks given to a wide audience and the project was to be open to the public (specifically children and families). The SBT documented the process using film and photography, and used blogs to report progress and discovery. Importantly, the findings were disseminated as part of the project - 
interpretative materials both on and off-site, as well as an exhibition, included the resulting archaeological data and research. After a competitive tender process, Birmingham Archaeology became the project's archaeological lead. To ensure the research element's robustness, and that we realised all avenues of investigation, the project formed an Academic Advisory Group. This Group met once a month for a site tour and progress updates. The Group included archaeological representatives from English Heritage (now Historic England), County Archaeologists and historic building specialists, and also Shakespearean academics.

\section{Project specifics}

From the outset, there was an innovative approach to the excavation - the SBT did not wish for professional archaeologists to excavate the site. Volunteers, mainly from the local community, undertook the excavations, under strict archaeological supervision. The excavations ran from 2010 until 2016, involving over 200 volunteers (Figure 1). Being a site of special historical interest ensured participation from a wide range of individuals. Everyone had different reasons for involvement, including interest in archaeology, or Shakespeare, boredom, friendships, charity work, previous archaeological experience, historical or literary interest. Evidence for this comes from anecdotal discussions with volunteers and post-project questionnaires. Throughout the project volunteers were encouraged to take ownership of the site. For many, their interest in discovery gave way to genuine desire to develop their archaeological technique and support the project. 


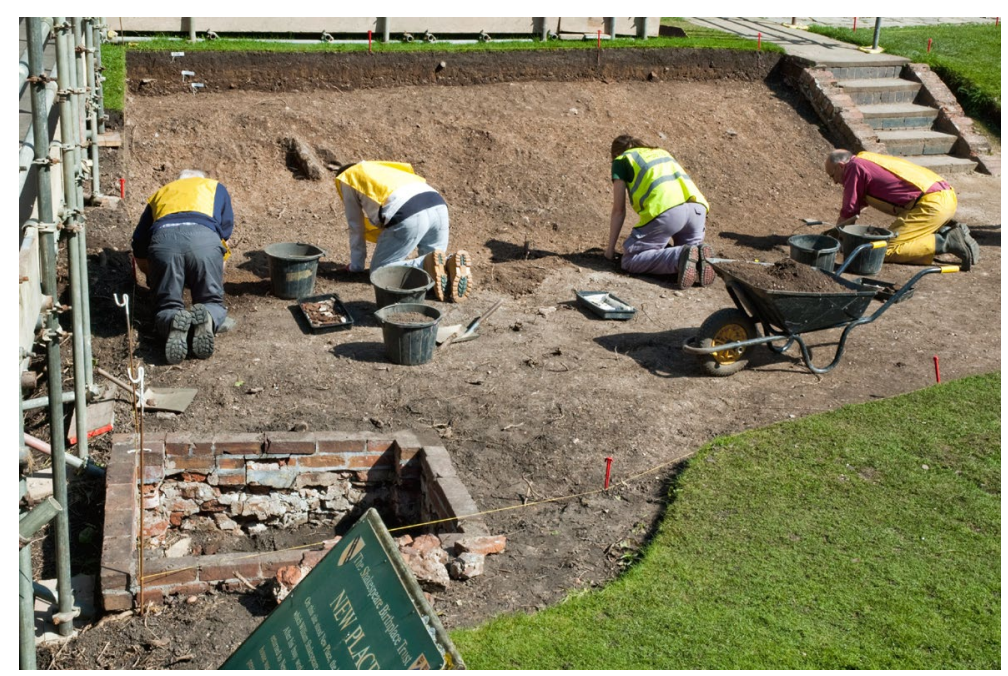

Figure 1: Excavation being undertaken by volunteers on the site of New Place, Stratford-upon-Avon (Copyright Malcolm McMillan).

Volunteers worked in morning and afternoon shifts and the project ran daily over a 28 week season annually for the first three years. The SBT took care of the project administration. Groups of volunteers who were organized together at the outset remained together throughout the project's six-year period (Edmondson, Colls and Mitchell, 2016). Although the project primarily involved volunteers living in the region, a call for volunteers on the SBT website (reaching thousands of viewers) attracted volunteers from overseas (e.g. USA, Canada and South Korea). The project engaged the wider Shakespearean community across the globe in conjunction with more local community groups and the interplay and engagement between these added new dynamics to the project. The site was open to the paying public, and they accessed the site through the adjacent historic house and museum. Throughout the course of the project, over 220,000 visitors witnessed the excavations. The public were able to interact with the volunteer archaeologists, ask questions and give their opinions (Figure 2). 


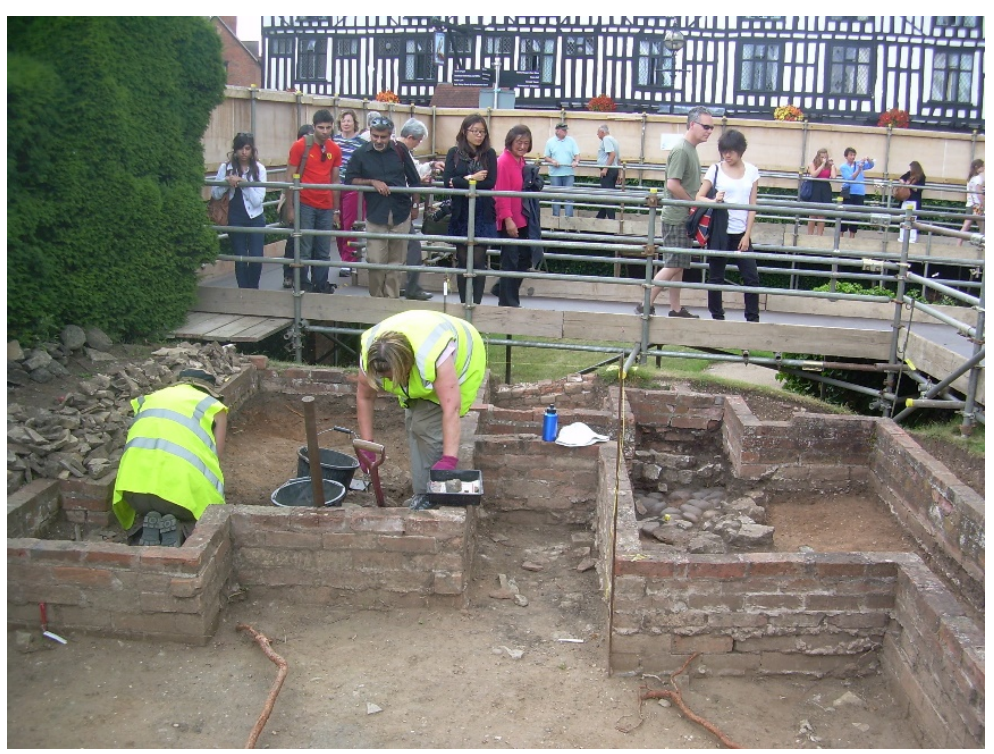

Figure 2: Excavation, undertaken by volunteers and overlooked by paying visitors to the site of New Place, Stratford-upon-Avon (Copyright William Mitchell).

Visitors were also able to participate in the archaeological process by sieving the soils removed from the excavation, and cleaning some of the un-stratified artefacts. Sieving was an archaeologically useful exercise and worthy of volunteer participation. In a newly erected marquee, the sieves used were wooden cradle sieves and larger swing sieves; both would take one or two people to operate (Figure 3). Soil was transferred from the site and passed into the sieves whilst maintaining relevant contextual information (Figure 4). 


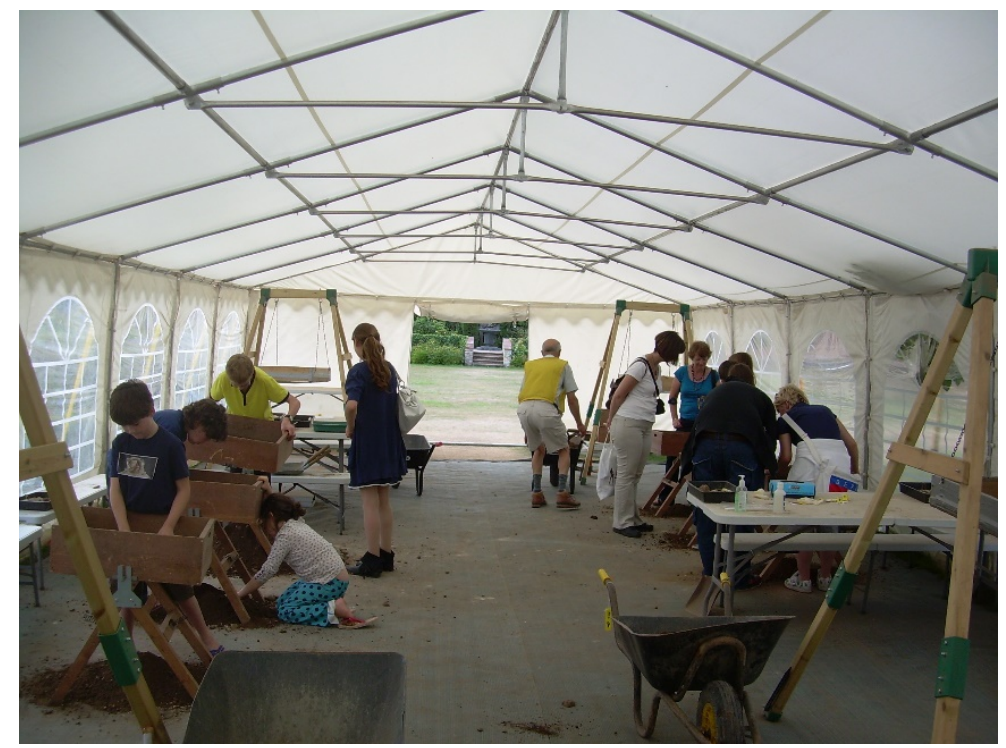

Figure 3: The sieving tent with volunteers and paying public at New Place, Stratford-upon-Avon (Copyright Malcolm McMillan).

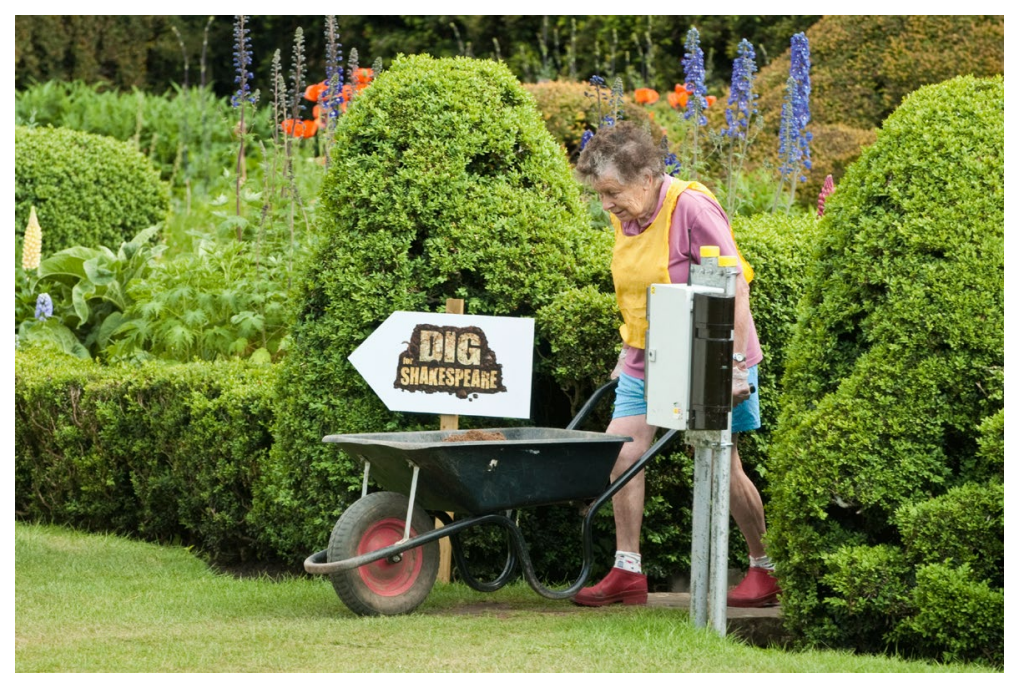

Figure 4: Volunteer with wheelbarrow containing soil to be sieved at New Place, Stratford-upon-Avon (Copyright Malcolm McMillan).

Sieving gave the volunteers and visitors a constant source of hands-on archaeological activity. The comprehensive nature of the material provided an additional resource to interpret during post-excavation. As such, the contribution of all those involved was relevant and important to the site's narrative. This 'live' aspect of the project did much to encourage community support and increase the project's reputation (Figure 5). 


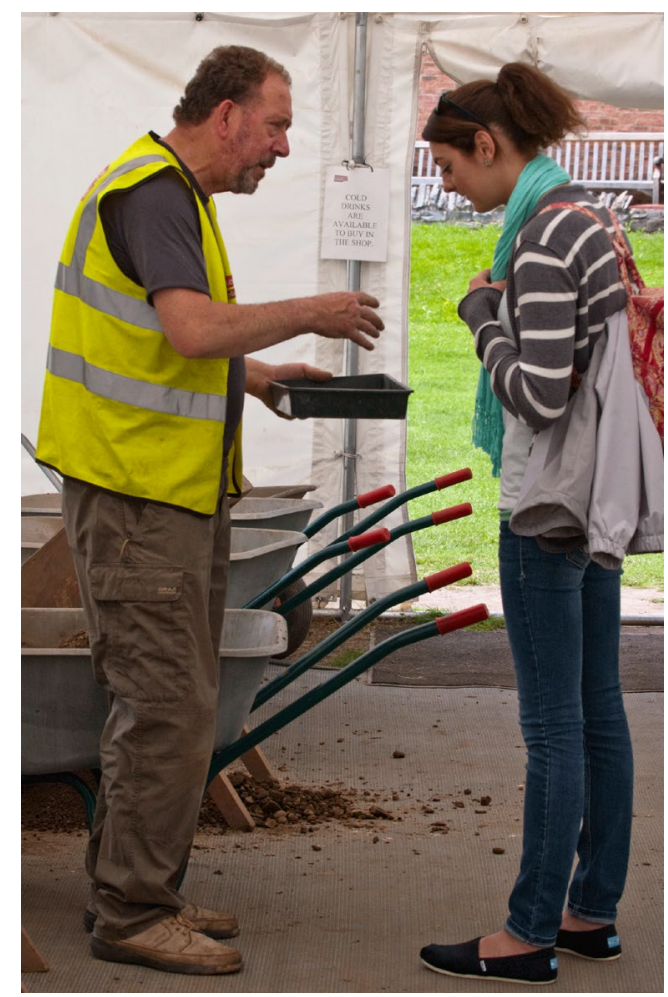

Figure 5: Volunteer disseminating learnt knowledge of artefacts recovered from the sieving tent at New Place, Stratford-upon-Avon (Copyright Malcolm McMillan).

In addition, we installed a second marquee to provide a facility for education, filling it with a variety of archaeological activities for children and families.

\section{Project successes}

The Dig for Shakespeare project outputs encompassed the volunteer and public aspects and ensured high standard archaeological research and heritage protection. New Place was open to the public before Dig for Shakespeare, and visitor numbers to the site increased each year during the project, directly attributed to the archaeological project's presence. The $2016 / 17$ season visitor numbers were 142,000 , an increase of $40 \%$ on the pre-project figure. On average, 250 attended 'Junior Archaeology' sessions at New Place each year and in 2013 alone 10,481 children and their families enjoyed the archaeological activities in the family marquee. In 2012, 29,000 voluntary hours were donated to the SBT; mainly associated with the archaeology project; a $16 \%$ increase from previous years. 
The sieving exercise was an additional and highly successful element. It worked as a means of recovering archaeological information, ensuring volunteer satisfaction and as a way to engage the visiting public. The constant supply of sieving material presented the opportunity of genuine discovery to volunteers and visitors who would otherwise have only played an ephemeral part.

Because of the project's success, several other outputs were possible. These were outside the project's brief but were beneficial to publicity and disseminating project results. The project featured on local television and in numerous newspapers and online news sites. It was also the subject of two BBC television features and a Time Team special ${ }^{\mathrm{i}}$. There were several conference papers and at the end of the project Manchester University Press published Finding Shakespeare's New Place: An Archaeological Biography (Edmondson, Colls and Mitchell, 2016). Upon completing the project, the SBT redesigned the site and, perhaps more importantly, reinterpreted it. A new design and layout for the site was completed alongside new landscaping, exhibits, narratives and interpretation boards. Much of this was driven by the results of the archaeological project and led to a $40 \%$ increase in visitor numbers $(142,000)$ to the site in 2017.

A number of study days hosted by the SBT and presented by us, took place towards the end of the project. These study days were fee paying and received good attendance, particularly from volunteers who wanted to pursue their interest further and used the opportunity of additional study days to embellish the information and knowledge already learned on site. Although these study days were not free to attend, each participant received a pack that included up to date site information, and later, a copy of the book.

Towards the project's end, several of the volunteers had developed enough confidence and archaeological knowledge to undertake their own presentations on the project results to 
their respective history groups. Further to this, several volunteers are currently employed as interpreters for the site; their experiences have enabled them to develop a career in heritage. Other regular volunteers became experienced and confident enough to undertake all the general archaeological activities on the site and were able to contribute effectively to interpretation. These skills primarily centred on traditional excavation; this provided the volunteers with the most direct link to the archaeology that they were familiar with, as championed in the media by the likes of Time Team. It is this version of archaeology which seems to capture the public imagination the most (Simpson and Williams 2008, 75; Tripp 2011, 28, Simpson 2009, 60). Volunteers were thus able to experience the traditionally accepted version of archaeology and make their own exciting discoveries. The favourable public perception of archaeology, due to many years of media exposure, has meant that projects can readily recruit volunteers and have the support of interested community members.

Finally, it also became clear that many of the volunteers in the working groups became close friends with each other. Indeed, even though the project is now complete, many still arrange to meet for social events. For example, the group that volunteered on Tuesday mornings still meet for lunch on that day, as that was their routine during the project.

Three years' work in the sun and dust, rain and mud involved many social interactions. With my fellow diggers I made friends. Having worked on all 14 shifts I met and grew to know lots of local people, many of whom I am still in contact with today. (Mr Richards, community volunteer, the Dig for Shakespeare Project pers comm., August 2015)

\section{Challenges}

This project attracted and engaged huge numbers of volunteers and visitors. However, we cannot quantify how much of this popularity was down to the 'Shakespeare effect' as opposed to archaeology. Clearly, without the cultural legacy of William Shakespeare there would have been no project. With the benefit of hindsight, to answer this, it would have been pertinent to produce a survey questionnaire for volunteers and visitors. 
Volunteers also had the opportunity to develop their surveying, recording and postexcavation techniques so that they experienced a well-rounded and more holistic view of archaeology, its purpose and methods. Individual reactions to these unfamiliar elements of archaeological fieldwork differed greatly. In many cases, volunteers did not readily accept these experiences. This was due to the unfamiliarity and complexity of the techniques, and their expectations of archaeology as a means of discovery rather than analysis. This perhaps can be considered as a negative effect of mainstream archaeology television programmes given that excavation and discovery play such a large part of how they 'sold' archaeology to mass markets. Over time, many of the volunteers achieved competency through a mixture of ongoing mentoring from professional archaeologists and support from more experienced volunteers.

The excavation process also presented several important challenges. Firstly, professional archaeologists need to ensure that any archaeological remains are excavated and recorded in an accurate and ethical manner (CIfA 2014a and b). This requirement is perhaps even greater if the site is of international importance. How can these levels of professional integrity be maintained if the excavation team consists of volunteers with little or no archaeological experience? One clear way forward is to target parts of the site deemed of lesser importance during the project's initial stages. This enables a training period to take place in advance of excavating the site's more sensitive parts. To achieve this at New Place, we excavated a series of archaeological test pits prior to the project's start in order to understand better the site's stratigraphy. This process identified that a large section of the site comprised of the backfill from a previous archaeological project carried out in the $19^{\text {th }}$ century by Shakespearean scholar James Halliwell-Phillips. This backfill proved to be a valuable training asset in teaching the principles of archaeological excavation.

Another issue that the excavation process raised is health, safety and volunteer wellbeing. The age and fitness ranges across the volunteers were highly variable. We discussed 
medical conditions beforehand, putting in place suitable mitigation strategies. Archaeological excavation can be physically challenging at times so we required daily consideration of volunteer capabilities, needing careful management as many of the volunteers were keen not appear to be letting the team down by not participating in some activities, for example taking full wheelbarrows to the sieving tents: '.. and this dig required a lot of spoil transferring around the site. For some it became known as a free "keep-fit" class ran by archaeologists' (Mr Lister, volunteer on the Dig for Shakespeare Project pers comm. July 2015).

It was clear through reviewing the sieved material that in the usual process of excavation much can be missed, particularly when volunteers are involved. We recovered several hundred additional artefacts. Without volunteers and visitors contributing to this process, this additional information would not have been recovered. This project benefited from sustained volunteer and visitor numbers, ensuring that the sieving was always manned, and could keep up with the pace of the excavations. Other community projects might not have the required numbers to do this.

Finally, one significant challenge towards the end of the project was that of the final publication. Given the unique and important evidence discovered, and the professional requirements placed on archaeologists to publish, a book had to be one of several end outputs. However, funding for a publication of this type was not part of the HLF project. The research lead from the SBT worked closely with the authors to bring the publication to fruition, but this was an unfunded activity. The process took close to a year. Being at Staffordshire University, we were able to work on this project through several research days throughout the year, but the majority of the work took place in the authors' own time. This process would have been even more unlikely if the successful archaeological contractor had been a purely development-led commercial unit. 


\section{St Giles Churchyard, Newcastle-under-Lyme}

\section{Background to the project}

The St Giles Community Heritage team initiated the St Giles Churchyard project in 2016 after detailed consultation with Staffordshire County Council, the local community and the HLF (Mitchell 2016). The project's purpose was to redevelop the $19^{\text {th }}$ century churchyard of St Giles to modernize the outdoor space for congregation ceremonies. Foremost amongst the project's many aims were the capital works needed onsite for its redevelopment. The requirement to redevelop the churchyard space whilst ensuring community involvement remained the main objectives. Community meetings before the start of the project helped to raise issues and recruit volunteers. A large spoil mound measuring some $50 \mathrm{~m}$ in length $4 \mathrm{~m}$ high, formed from the demolition of the previous church that once stood on this site, occupied much of the churchyard. This mound's removal constituted the project's focus. Due to the seclusion which the spoil mound provided, the space had become underused and a target for criminal activity, such as drug and alcohol misuse and vandalism. The St Giles Community Heritage team organized a consultation with the parishioners to generate informed ideas and to confirm suitability for its future use.

The mound was the result of significant developments in the later $19^{\text {th }}$ century. St Giles church, which was built in 1720-21 on the location of an earlier medieval church, was considered too small and dilapidated for the significant congregation and, thus, a larger church and churchyard was proposed. In 1873 all but the original medieval tower was demolished. The resulting rubble and spoil was piled into three large heaps around the new Victorian church. During this $19^{\text {th }}$ century redevelopment, it was known that graves within the church and cemetery would be disturbed. Crypts were built to contain the disturbed remains, but many of these ended up mixed within the spoil heap. Two of the three mounds were levelled in 1898 
when the cemetery was enlarged, but the third remained untouched. It was this mound that was the focus of the modern excavations. Given the known site history and evaluation results, the spoil mound was to be removed archaeologically. The main archaeological aim was to recover architectural and disarticulated human remains from within the mound using a process of sieving and to complete a detailed study of the recovered remains. Volunteers were essential to achieve this goal. The project team received funding from the HLF.

\section{Project Specifics}

From the outset, it was clear that there were would be ethical issues. Before excavation, there was an archaeological evaluation of the mound to assess its composition. Professional archaeologists completed this and confirmed the presence of disarticulated human remains and fragments of church architecture. Based on these results, and after discussion between the Church, the Centre of Archaeology, and the community groups and parishioners, we concluded that the majority of the mound would be sieved using the same apparatus as in Dig for Shakespeare. Once removed, professional archaeologists would deal with any in situ crypts, or burials that needed exhumation and reburial. The basis for this decision was the disarticulated nature of the remains within the mound and their limited scientific value compared to complete burials. Community volunteers were nonetheless going to be in contact with human remains.

Recruitment and training took place with care to ensure that volunteers were aware of all the issues associated with this work and the discoveries they were likely to encounter. It was also important for the project team to know that those participating were suitable. Exposure to human remains, albeit historical, had the potential to cause distress. The volunteers would also be present during the professional excavation of any in situ burials (Figure 6). 


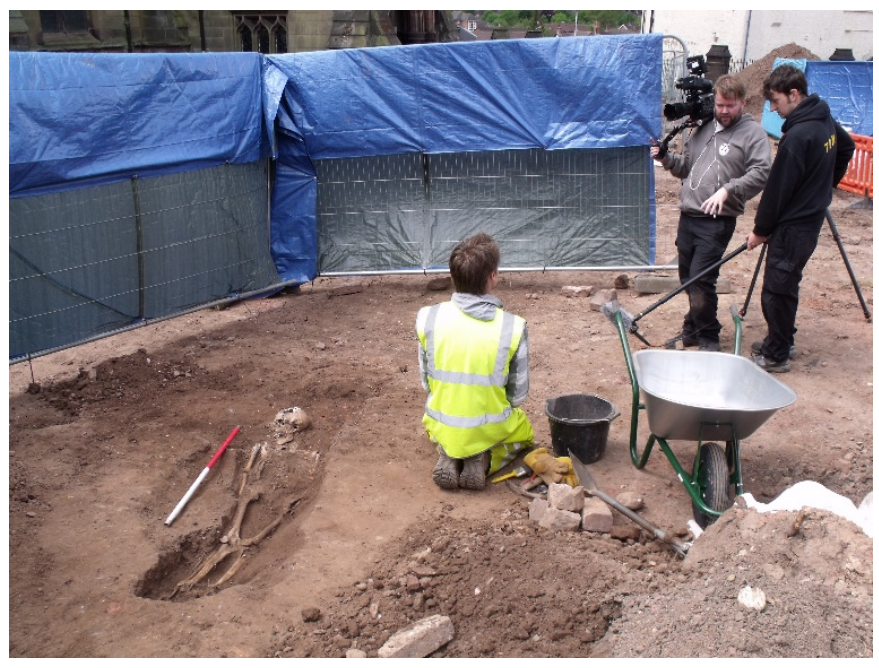

Figure 6: Media interest in the excavations of St Giles Churchyard, Newcastle (Copyright Kevin Colls).

We asked volunteers to fill out a questionnaire giving their reasons to participate. The decision-making process was open and ultimately it became self-selecting as those potential volunteers who did not find this project suitable decided not to continue. We also carried out in-depth discussions with potential volunteers. Based on responses, only a small number of applicants were not accepted on the project.

The project involved up to 10 volunteers per day, equating to a considerable number of volunteer hours over the project's course (around 500). In addition, the volunteers learned the process of 3D laser scanning to scan a selection of archaeological finds from the excavation, enabling creation of a 3D catalogue of objects - a virtual museum - that was intended would ultimately be available online, and the results disseminated as part of the project.

\section{Project Successes}

The St Giles churchyard community project proved successful both for volunteer satisfaction and artefact recovery. Many volunteers continued for the project's duration, attending between two and three days per week. The project's success and the interest generated led to many volunteers participating in additional workshops and project-related research after the main site work, including osteological training sessions and a 3-D laser scanning and printing workshop. 
Two volunteers commenced post-graduate studies in forensic archaeology as a direct result of their experiences. Several volunteers went on to establish their own community archaeology projects and others secured funding to develop the work of their local archaeological society.

An archaeological report on the project's results was produced and we are close to completing an archaeological journal article. A brochure detailing all the churchyard redevelopment project's elements was completed alongside several open days.

An important project output was that all the human remains and other archaeological objects from the mound were recovered during the excavation and sieving process. An osteoarchaeologist, who also worked in a mobile lab on the site in conjunction with the volunteers, analysed and reported both the disarticulated and articulated human remains (Mitchell 2016). All the remains were later reinterred within the churchyard by the vicar after a short sermon.

Despite there not being public involvement at every stage, the community of St Giles and Newcastle-under-Lyme directly benefitted from the redevelopment, and now have a greater knowledge of their church's history through the disseminated results and usable churchyard space. The benefits included positive feedback from the church community and the reduction of criminal activity on the site.

\section{Challenges}

Some groups within the community itself were either reluctant, unwilling or unable to contribute more significantly to the archaeological project. Others made it clear that they did not support the project objectives in any way. Since the churchyard was a public space there was interest from the local community throughout the project. Most of the visitors were generally supportive, but there were those who saw the removal of the spoil mound as a desecration of a sacred space. These feelings were verbalized to the team working on the site. On these occasions where such individuals expressed their objections, we needed to explain 
the future for the site and discuss the project's merits. This was usually enough to appease most criticisms, but not all. The project also closed much of the churchyard for the duration, which impacted upon parking and a pedestrian short cut to the town centre. To some, these issues represented their major concerns rather than the disturbance of the human remains.

As with Dig for Shakespeare, the volunteers themselves were much more open to the 'hands on' archaeological activities rather than analysis or documentation. With the primary activity being sieving, it was sometimes difficult to motivate the volunteers, particularly when archaeologists working elsewhere on the site were completing other archaeological excavation tasks. Working with community volunteers to produce research outputs after fieldwork ended proved to be more difficult than the on-site work, although some volunteers really did excel at this too. Whilst these practical applications were completed on site, the process of creating a virtual museum was ultimately not completed due to lack of further funding.

The project specification and ethics proved difficult from the outset. For the HLF funding, the project certainly placed a priority upon completing the capital works (the removal of the mound and the churchyard redevelopment). The applicants to HLF, the Heritage Churchyard Team, followed guidance and approached the planning archaeologist for Staffordshire County Council and they created a project brief. At the tender stage, this brief was made available to the archaeological contractors. The project brief covering this work recommended that the mound could be removed mechanically under archaeological supervision - a watching brief. Although a common archaeological method in developer-led projects, at the tender stage we felt that this approach did not account fully for the ethical nature of the work. Completed this way, a significantly high percentage of the human remains and artefacts would have been simply removed without further investigation. Creating a community volunteer project acted as a method by which this process could be completed without the loss of important objects and human remains. Of course, this opened other ethical debates on the 
use of volunteers and the excavation and handling of human remains. For this type of project, this approach, due to its careful handling, proved successful. However, the work at St Giles perhaps can be seen as a unique case, rather than setting a precedent for subsequent community archaeology projects.

\section{Discussion}

\section{Two case studies: A critical assessment of community archaeology}

In these projects, as with other similar examples in recent years, participation was most prevalent in certain groups of people (Woolverton, 2016). Most volunteers involved were retired and able to contribute regular hours to the projects. An interest in archaeology was a key motivator on these projects and is the main reason for community archaeology involvement in general. Most of the volunteers had time to spare. They identified pursuit of personal development, interest in archaeology, feelings of shared ownership, feelings of investment in the site's history and desire for knowledge as some of the reasons behind involvement. Some used these projects as an opportunity to meet people and make friends, and of course there were personal factors which effected everyone's decision for involvement. During the authors informal conversations with the volunteers, numerous reasons were cited for their involvement. Among these were the development of personal skills and knowledge, their sense of connection to the past, the chance to support the project and the opportunity for career development. Similar motivations have been recorded from other community archaeology projects (Simpson $2008,11)$.

The type of site investigated can also be a factor. The Dig for Shakespeare project was successful because of peoples' continued interest in the life, works and times of William Shakespeare. The St Giles churchyard project achieved partial success, as many of those who 
were involved were personally invested in the outcome, being members of the parish church congregation.

At each site a small number of volunteers were already studying or would soon study archaeology at degree level. These projects provided the opportunity for those needing to learn archaeological techniques and add this experience to their portfolio.

The volunteers undertook archaeological activities which were rotated for a degree of fairness. This was initially co-ordinated by the archaeologists however, over a period of time, the volunteers developed their own preferred roles and specialisms which allowed the projects to run more autonomously, without constant professional supervision. In fact, the collective experiences of the volunteers occasionally demonstrated new ways of working that the archaeologists took on board for future projects, for example practical solutions to improve sieving methodology and public interactions. Some volunteers preferred public facing roles and took it upon themselves to promote and disseminate the project to the public who visited these sites, whilst others preferred the practical side such as excavation or sieving. They sought guidance from the professional archaeologists when required, but the volunteers established hierarchies and roles between themselves depending on confidence, ability, commitment or interest.

\footnotetext{
Our group consisted of a wide range of people, from all walks of life, most of which had never had the opportunity to do anything like archaeology before. There was also a wide range of ages: we had two 16 year olds through to retirees. It was interesting to watch the group gel and work as a team as time went on, people began to find their niche in the process. We all became more confident, and I think the majority of us tackled areas that were a little out of our comfort zone. (Mrs Dodd, volunteer on the Dig for Shakespeare project, pers comm. August 2016)
}

The roles of volunteers supplemented the professional archaeologists. Many of them were well placed to be able to disseminate complex archaeological ideas and techniques to one another and to the visiting public. As has been the case on community archaeology projects 
elsewhere (Simpson 2008; Simpson 2009; Simpson and Williams 2008), excavation and handson activities such as sieving were a vital component in volunteer retention and the success of these projects. Simpson found that: '[T]o the amateurs, involvement in excavation increased the desire to be involved in further excavation and partake in more training, including college and university courses' (Simpson 2009, 57).

Recruitment and retention often proved to be challenging on these projects; St Giles churchyard had difficulty in recruiting and retaining volunteers. On the Dig for Shakespeare project, we had the opposite problem. Around 200 people volunteered across the five seasons and initially, for the first three seasons, this was for seven days a week. This meant that we had to introduce a shift system to cover the week with each day split into two shifts. This model ensured that every day had allotted volunteers who were committed to returning on the same day each week. This model also allowed for working individuals to organize their volunteering around their employment. It created a good rapport between the members of each group and even promoted healthy competition between them. Volunteers developed friendships, and this fuelled their commitment to return. It is also clear that a varied distribution of volunteer ages and backgrounds can enhance the volunteer experience and may contribute to improved attendance.

It was particularly important that the results were disseminated through media outlets. This let the wider public know about the projects and assisted in promoting the work, which further increased volunteer numbers. The results, once disseminated, had a lasting impact on the community, giving them new insights into their history and greater ownership of their past.

For the professional archaeologists working on these sites, the use of volunteers could often be challenging and there were some logistical issues. The main disadvantages in these projects occurred due to staffing and attendance. There were occasions when the number of 
volunteers on site fell below the number needed to do the work. This effect is a recognized feature of community archaeology projects (Belford 2011) and perhaps the whole model of community archaeology projects needs to be revised to account for this. Volunteers could not always turn up and absences were often not communicated beforehand to the archaeologists. For volunteers there is no written requirement to turn up on time, or even turn up at all. There were often uncertainties as to how many volunteers were going to attend at any one time, despite a comprehensive sign-up procedure in place. This meant that job allocation and project planning was constantly under revision.

Unlike development-led projects in the UK, in community archaeology projects the post-fieldwork responsibilities do not always explicitly follow the NPPF guidelines (National Planning Policy Framework- UK government guidance), the guidelines of the local planning authority, or the Standards of the Chartered Institute for Archaeologists (CIfA). On occasion this may mean that the project archive does not receive the same attention as other traditional archaeology projects and may be difficult to access for future researchers. A recent Historic England report on community archaeological research explores this issue (Hedge and Nash 2016). In the case of the projects discussed above and most other professionally-led community archaeological projects, each of the project initiators were able to receive the archive (being a museum and a church) and the reports were disseminated through the local Historic Environment Records (HERs), whether funding was in place through the HLF grant to cover this or not.

The legacies of community archaeology projects are important and often play a crucial role in the HLF application process. Legacies can be varied and far-reaching, but also can be subtle and unassuming. For some, individual legacies can be seen, for example volunteers who go on to study and graduate in archaeology or set up their own archaeological groups, undertaking archaeological projects in their own communities. Other legacies are more 
community driven, such as the transformative effect of a re-development like at St Giles. What is clear is that discourse with the community volunteers should not end with the excavation's completion. It is a necessary and worthwhile exercise to enable the volunteers to collaborate at all stages of the research. In this model, those who contributed took much more of a feeling of ownership of the site rather than the individual volunteer who assisted for only a few hours each week (Tully 2007, 159; Peers and Brown 2003, 1).

\section{An assessment of community archaeology and the Heritage Lottery Fund}

For some institutions such as charities, achieving financial security has become increasingly difficult. Through the HLF funding process, projects can happen where previously they may not have done. The HLF makes a welcome and valuable contribution by supporting the existence of the heritage conservation and research community. Due to the increasingly limited opportunity for government financial support, small heritage groups rely on HLF funding. To access this funding, groups need to ensure their project meets the HLF criteria. In some cases, this may mean that projects need refining to ensure that HLF objectives are met. For each of the projects described above the inclusion of the community archaeology element to the project helped to meet HLF objectives. In this respect, the availability of HLF funds were critical. The impact and contribution that volunteers had on these projects was undoubtedly important, and without them the projects would not have taken place.

The HLF objectives and the professional archaeological community are not always aligned. HLF priorities lie with ensuring that projects fulfil their responsibilities to the people involved and the community which is being served, whereas for professional archaeologists, the non-renewable archaeological record often takes priority. Archaeological excavation, whether linked to a community project or not is, inherently a destructive, non-repeatable process. 
Given the competitive nature of the process, the archaeological contractor commissioned to undertake the community archaeology tasks may not have been involved in the project application and project design. It is not the remit of the HLF to ensure that community archaeology projects are treated in the same way as traditional developer-funded archaeological projects (HLF 2018b). In the UK, the CIfA monitors professional archaeology. Although membership is voluntary not mandatory, through Standards and Guidance Policies (CIfA 2014a and b), and Code of Conduct regulation (CIfA), the CIfA specify best working practices for archaeological investigation. These include a commitment to liaise with local authorities (Historic Environment departments at County Councils) and national bodies (for example Historic England), publish and disseminate archaeological data, understand local, regional, and national research frameworks at planning stage (to identify gaps in archaeological knowledge), and to ensure resources are in place to protect and conserve any discoveries made during the archaeological process. As outlined in the current HLF good practice guide, archaeological contractors involved in projects are subject to the same expectations as those defined by the CIfA. However, it is entirely possible that some or all of these mainstream archaeological requirements do not form part of the HLF project proposals. So, it is possible for projects to receive funding that do not meet the requirements as specified by the CIfA. The responsibility then falls upon the archaeologists to ensure that these standards are met.

At the time of writing, the HLF is in the process of planning its new strategic framework, which is due to begin in 2019. A review of current HLF framework by the UK's Department for Digital, Culture Media and Sport records that the:

...HLF is operating within the context of reducing National Lottery receipts and local authority funding. As a result, it recommends that HLF should become more strategic, effective and efficient to ensure National Lottery funding continues to support the resilience of the heritage sector, benefits people and preserves heritage for future generations. (HLF 2018c) 
Planned changes will follow the recommendations for new ways of working, such as simplifying the grant giving processes and operating more efficiently. These changes are in response to a reduction in the National Lottery Good Causes income given to the heritage sector. The planned changes are likely to influence the funding, selection and continued evaluation of future community archaeology projects. The HLF selection process for future community archaeology projects is likely to alter considering these developments, but it remains unclear if more robust archaeological methodologies will form part of these changes.

\section{Conclusion}

The traditional 'top down' archaeological project, funded by the HLF and adapted so that community involvement becomes the driving force, can be successful and necessary. Recent email discussions between the authors and Sara Croft, Head of the Historic Environment at the HLF suggest, however, that these professionally-led community archaeology projects are currently not the norm;

From my own experience I would say that most community archaeology projects that HLF funds genuinely grow out of an idea generated within a community group; projects that appear to be professional archaeological research with an element of community engagement added to them rather than embedded in them are less likely to be supported. (Sara Croft, pers. comm, 2018)

However, this implies that this system can and does result in scenarios whereby a community-driven project idea with archaeological elements can be commissioned through the HLF without any consultation on methodology, outputs, or costs from professional archaeologists. For the two case studies discussed in this paper, the project designers did take advice from archaeologists, alleviating many issues, but still not all. The usual pressures and finances to produce a report to satisfy planning conditions, to archive a project properly, and to publish the results are not always present in community archaeology ventures and, in this, the archaeological responsibilities rely more on the professional ethics of the archaeologists 
involved. To ensure sustained success for future professionally-led community archaeology projects, perhaps the responsibility for monitoring projects by the HLF should continue to ensure that the archaeological data generated is disseminated and published as a matter of routine. As discussed above, these changes may well be underway with the current review of HLF operations.

The types of communities involved in the projects discussed in this paper validates the question of what constitutes a community. Although each of the projects involved volunteers from the immediate community, volunteers also came from much further afield to take part and the term 'community' was a much wider concept. Discussion on this is comprehensive (for an example see Thomas 2017). For each of the projects, the community involved was not only those who lived in the immediate area but those who had an interest in archaeology or Shakespeare, or their local church, and were able to commit their time to support these specific sites. A wider group of people also benefitted from these projects due to the lasting outcomes (in particular, the redevelopment of buildings and places to ensure their ongoing use). The Dig for Shakespeare project provided the model for the St Giles project, but the unparalleled successes achieved on this project likely lies primarily in the Shakespearean influence. However, the extensive marketing and advertising programme undertaken for this project also ensured a greater chance of success. Not all projects have the finances to achieve marketing and public relations to this extent.

It is beyond doubt that archaeological and heritage sites have benefitted from the HLF. These two projects are a testament to this. Without this funding, many sites would not receive the attention they deserve. The stipulations placed upon these projects by the HLF framework which require that heritage, people and communities' outcomes are met, are designed to ensure that a certain type of project takes place. The HLF criteria for acquisition of funding often leads to an increase in community volunteer activities. Through involving volunteers, projects can 
immediately meet a number of these essential HLF criteria. If the proposers of community HLF projects receive archaeological input into the application and bid writing process, then this represents the best way to ensure that all aspects of the archaeological process are met and fully costed into the project. Another possible solution revolves around more strict funding regulations at application stage to ensure that any prospective project has accounted for all archaeological tasks, including archiving and publication. Each of the two case studies in this paper were successful in delivering well-supported and popular archaeological community volunteer projects funded through the Heritage Lottery Fund. This success can be quantified by the numerous outcomes highlighted in this paper and the added value to both the individual volunteers and to the local environment.

\section{Acknowledgements}

We would like specially to thank Suzie Thomas for her expert support and advice during the many revisions of this paper, Sara Crofts of the HLF and Caroline Sturdy Colls for her suggestions. We would also like to thank all those who made the Dig for Shakespeare and St Giles Churchyard projects possible including all the staff and volunteers involved, without whom these projects would not have been so successful.

\section{References}

BDRC, Mills, Steve and Jon Young. 2009. Impact of HLF Funding 2005-2009. Visitor Surveys 2005-9. London: BDRC.

https://www.heritagefund.org.uk/sites/default/files/media/research/impact_hlffunding_visitor sreport2009.pdf 
Belford, Paul. 2011. Archaeology, Community and Identity in an English New Town, The

Historic Environment, Vol. 2 No. 1, June, 2011, 49-67, W.S Maney \& Son Ltd. doi:

$10.1179 / 175675011 X 12943261434602$

Belford, Paul. 2014. Sustainability in Community Archaeology. AP: Online Journal in Public Archaeology. Special Volume 1. 21-44, JAS Arqueologia S.L.U. doi:

http://dx.doi.org/10.23914/ap.v4i2.58

Carman, John. 2005. Against cultural property: Archaeology, heritage and ownership.

London: Duckworth. doi: https://doi.org/10.1017/S0940739108080053

CIfA, 2014a, Standard and guidance for archaeological investigation. Accessed 6 August 2019 https://www.archaeologists.net/sites/default/files/CIfAS\&GBuildings_1.pdf

CIfA, 2014b, Standard and guidance for archaeological field evaluation. Accessed 6 August 2019 https://www.archaeologists.net/sites/default/files/CIfAS\&GFieldevaluation_1.pdf

Croft, Sara, 2018. Personal Email Communications

Department for Communities and Local Government. 2012. National Planning Policy Framework. Accessed 6 August 2019

https://assets.publishing.service.gov.uk/government/uploads/system/uploads/attachment_data /file/810197/NPPF_Feb_2019_revised.pdf

Edmondson, Paul, Kevin Colls and William Mitchell. 2016. Finding Shakespeare's New Place; An archaeological biography. Manchester: Manchester University Press.

Grant, Kevin, 2014. Canals, Cake, and 6H Pencils: Starting Out in Community Archaeology, Journal of Community Archaeology \& Heritage, 1:2, 137-154. Routledge. doi: https://doi.org/10.1179/2051819614Z.00000000010 
Hedge. Rob and Aisling Nash. 2016. Assessing the value of community-generated historic environment research. Historic England. Accessed 6 August 2019

https://research.historicengland.org.uk/redirect.aspx?id=7086|Assessingthevalueofcommunity -generatedhistoricenvironmentresearch

Heritage Lottery Fund. 2017a. Evaluation. Good-practice guidance Accessed 6 August 2019 https://www.heritagefund.org.uk/sites/default/files/media/attachments/Evaluation\%20guidanc e.pdf

Heritage Lottery Fund. 2017b. Our Heritage. Grants from £10,000 to £100,000. Application Guidance. Accessed 6 August 2019

https://www.heritagefund.org.uk/sites/default/files/media/programmes/oh_application_guida nce.pdf

Heritage Lottery Fund. 2018a. Accessed 6 March 2018 https://www.hlf.org.uk/aboutus/what-we-do

Heritage Lottery Fund. 2018b. Accessed 31 January 2018 https://www.hlf.org.uk/lookingfunding/what-we-fund

Heritage Lottery Fund. 2018c. Accessed 6 March 2018 https:/www.hlf.org.uk/about-us/ourstrategy/tailored-review-heritage-lottery-fund

Maeer, Gareth, 2017. A People-Centred Approach to Heritage: The Experience of the Heritage Lottery Fund 1994-2014, Journal of Community Archaeology \& Heritage, 4:1, 3852. Routledge. doi: https://doi.org/10.1080/20518196.2017.1238098

Marshall, Yvonne. 2002. What is community archaeology? World Archaeology Vol.34 (2): 211-219. doi: 10.1080/0043824022000007062 
Ministry of Housing Communities \& Local Government. 2019. National Planning Policy Framework Accessed 6 August 2019

https://assets.publishing.service.gov.uk/government/uploads/system/uploads/attachment_data /file/810197/NPPF_Feb_2019_revised.pdf

Mitchell, William. 2016. St Giles Churchyard, Newcastle-under-Lyme. Archaeological Investigation, 2016. Centre of Archaeology, Staffordshire University Report PN 16-06

Peers, Laura and Alison Brown (eds). 2003. Museums and source communities. Routledge, London.

R.E.F 2021. Research Excellence Framework Guidelines. Accessed 3 March 2019.

https://www.ref.ac.uk/

Reid, Pat. 2008. Community Archaeology: From the grassroots. Current Archaeology, 216. 21 Accessed 6 August 2019 https://www.archaeology.co.uk/articles/opinion/communityarchaeology-from-the-grassroots.htm

Schadla-Hall, Tim. 1999. Editorial: Public archaeology, European Journal of Archaeology. 2:2, 147-158. doi:10.1179/eja.1999.2.2.147

Simpson, Faye. 2008. Community Archaeology Under Scrutiny, Conservation and MGMT of Arch. Sites, Vol. 10 No.1 February 2008, 3-16. doi: 10.1179/175355208X404303

Simpson, Faye. 2009. Evaluating the value of Community Archaeology: The XArch Project, Treballs d'Arqueologia, Num. 15, 51-62.

https://ddd.uab.cat/pub/tda/11349263n15/11349263n15p51.pdf

Simpson, Faye and Howard Williams. 2008. Evaluating Community Archaeology in the UK. Public Archaeology, Vol. 7, No.2, Summer 2008, 69-90. doi: 10.1179/175355308X329955 
Thomas, Suzie. 2010. Community Archaeology in the UK: Recent Findings, York: Council for British Archaeology. Available: https://www.sccjr.ac.uk/publications/communityarchaeology-in-the-uk-recent-findings/

Thomas, Suzie. 2014. Making Archaeological Heritage Accessible in Great Britain: Enter Community Archaeology in Public Participation in Archaeology, edited by Thomas, Suzie and Joanne Lea. 23- 34, Woodbridge: The Boydell Press.

Thomas, Suzie, 2017, Community Archaeology in Key Concepts in Public Archaeology edited by Moshenska, Gabriel. 14- 30, UCL Press, London

Tripp, Christopher. 2011. Why Community Archaeology? in Community Archaeology: Themes, Methods and Practices, edited by Moshenska. G \& S. Dhanjal. 28- 34. Oxford: Oxbow books.

Tully, Gemma. 2007. Community archaeology: general methods and standards of practice. Public Archaeology, Vol. 6, No 3, 155-187. Maney \& Son Ltd. doi: $10.1179 / 175355307 X 243645$

Winterton, Steve. 2014, From the Army Medical Centre to Operation Nightingale: My Entry into Archaeology. Journal of Community Archaeology and Heritage, Vol. 1, No. 3, September 2014, 245-247. Routledge. doi:

https://doi.org/10.1179/2051819614Z.00000000015

Woolverton, Jemima. 2016. Becoming History Ourselves: A Study of Age Demographics in Community Archaeology Societies. Journal of Community Archaeology and Heritage 3(2):135-151. Routledge. doi: https://doi.org/10.1080/20518196.2016.1154741 
' Time Team is a UK-produced archaeology television series that ran from 1994 to 2014. For more information, see https://www.timeteamdigital.com/. 